\title{
STX11 Gene Mutation
}

National Cancer Institute

\section{Source}

National Cancer Institute. STX11 Gene Mutation. NCI Thesaurus. Code C158651.

A change in the nucleotide sequence of the STX11 gene. 